\title{
A rare case of urethral prolapse in a postmenopausal woman
}

\author{
Jennifer Green, ${ }^{1}$ Andrew Brodie, ${ }^{2}$ Tariq Tassadaq ${ }^{1}$
}

'Department of Urology, Bedford Hospital NHS Trust, Bedford, UK

${ }^{2}$ Department of Urology, Lister Hospital, Stevenage, UK

\section{Correspondence to}

Dr Andrew Brodie,

andrew.brodie@doctors.org.uk

Accepted 7 October 2017
CrossMark

To cite: Green J, Brodie A, Tassadaq T. BMJ Case Rep Published Online First: [please include Day Month Year]. doi:10.1136/bcr-2017222182

\section{DESCRIPTION}

We present the case of a 74-year-old postmenopausal woman presenting with a 5-day history of dysuria, pain, urinary frequency and urethral bleeding. Her previous medical history included hypertension. Obstetric history included one forceps delivery and one normal vaginal delivery. On examination, an irreducible urethral prolapse was noted with bleeding urethral mucosa (figure 1).

Patient went to theatre; another attempt was made to reduce the prolapse which was unsuccessful. Cystoscopy was then used to examine the urethra and bladder which revealed evidence of cystitis. With the cystoscope in situ, manual reduction was possible. A 20 French urethral catheter was inserted and the urethral wall was buttressed with suture to maintain reduction.

Patient was discharged with topical oestrogen cream and the catheter has since been removed without recurrence of prolapse.

Urethral prolapse is a very rare condition with a bimodal age distribution most commonly occurring in prepubertal girls and postmenopausal women. ${ }^{1}$ The exact aetiology is unknown; however, several risk factors are postulated including hypermobility of the urethra and vaginal/urethral mucosal atrophy secondary to decreased oestrogen. ${ }^{2}$ Differential diagnoses include urethral caruncle, condyloma,

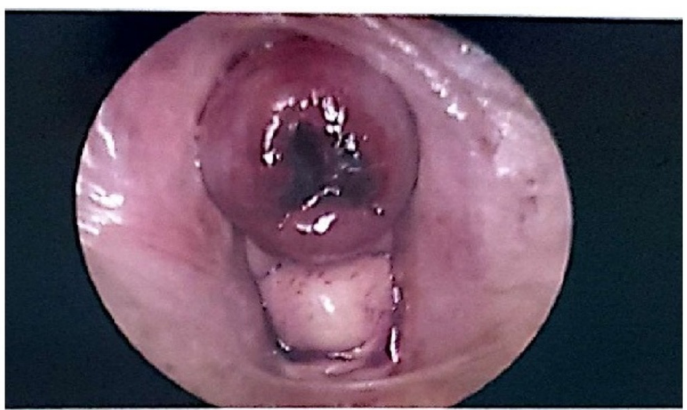

Figure 1 Image revealing prolapsed urethral mucosa. prolapsing ureterocoele and rhabdomyosarcoma. A variety of different management approaches have been employed ranging from conservative treatment with topical oestrogen to multiple surgical techniques. The most commonly reported surgical technique involved excising the mucosal prolapse and suturing to the vaginal wall with a catheter in situ. ${ }^{3}$

The surgical technique reported in this case has not previously been described and may represent a novel treatment when faced with this rare condition.

\section{Learning points}

- Urethral prolapse is a rare condition and thus there is currently no consensus on optimal treatment strategy.

- Cystoscopy is a valuable tool in confirming diagnosis and should play a role in surgical management.

- Buttressing of urethral wall to the anterior vagina may represent a novel surgical technique.

Contributors $J G$ and $A B$ were involved in the design, writing up and final drafting of paper; TT was involved in the final drafting.

Competing interests None declared.

Patient consent Obtained.

Provenance and peer review Not commissioned; externally peer reviewed.

(C) BMJ Publishing Group Ltd (unless otherwise stated in the text of the article) 2017. All rights reserved. No commercial use is permitted unless otherwise expressly granted.

\section{REFERENCES}

1 Surabhi VR, Menias CO, George V, et al. Magnetic resonance imaging of female urethral and periurethral disorders. Radiol Clin North Am 2013;51:941-53.

2 Mitre A, Nahas W, Gilbert A, et al. Urethral prolapse in girls: familial case. J Urol 1987;137:115.

3 Kleinjan JH, Vos P. Strangulated urethral prolapse. Urology 1996:47:599-601. 
Copyright 2017 BMJ Publishing Group. All rights reserved. For permission to reuse any of this content visit http://group.bmj.com/group/rights-licensing/permissions.

BMJ Case Report Fellows may re-use this article for personal use and teaching without any further permission.

Become a Fellow of BMJ Case Reports today and you can:

- Submit as many cases as you like

- Enjoy fast sympathetic peer review and rapid publication of accepted articles

Access all the published articles

- Re-use any of the published material for personal use and teaching without further permission

For information on Institutional Fellowships contact consortiasales@bmjgroup.com

Visit casereports.bmj.com for more articles like this and to become a Fellow 